\title{
Seroprevalence and risk factors for bovine brucellosis in Minas \\ Gerais State, Brazil
}

\section{Soroprevalência e fatores de risco para brucelose bovina no Estado de Minas Gerais, Brasil}

\author{
Luciana Faria de Oliveira';; Elaine Maria Seles Dorneles²; \\ Ana Lourdes Arrais de Alencar Mota ${ }^{3}$; Vitor Salvador Picão Gonçalves ${ }^{4}$; \\ José Soares Ferreira Neto ${ }^{5}$; Fernando Ferreira ${ }^{5}$; Ricardo Augusto Dias ${ }^{5}$; \\ Evelise Oliveira Telles ${ }^{5}$; José Henrique Hildebrand Grisi-Filho ${ }^{5}$; \\ Marcos Bryan Heinemann ${ }^{5}$; Marcos Amaku ${ }^{5}$; Andrey Pereira Lage ${ }^{6 *}$
}

\begin{abstract}
This cross-sectional study was conducted in the state of Minas Gerais, Brazil in 2011 to estimate the seroprevalence of bovine brucellosis (Brucella abortus) in properties and cattle, and to identify potential infection risk factors for herds with cows of reproductive age. The state was divided into seven regions: 1. Noroeste, Norte and Nordeste; 2. Leste; 3. Central; 4. Zona da Mata; 5. Sul and Sudoeste; 6. Alto Paranaíba; and 7. Triângulo Mineiro. Random, two-stage sampling was performed of both properties and cattle from each property. Blood samples were collected from 18,990 cows of reproductive age from 2,185 properties. The serologic tests used for the detection of anti-B. abortus antibodies included the buffered, acidified plate antigen test, as a screening test, with the 2-mercaptoethanol reduction, test as a confirmatory test, as recommended by the Programa Nacional de Controle e Erradicação da Brucelose e Tuberculose Animal - PNCEBT (National Program for the Control and Eradication of Animal Brucellosis and Tuberculosis). The seroprevalence of bovine brucellosis on the surveyed properties and in cattle were $3.59 \%$ (95\% confidence interval [CI]: $2.764 .42 \%)$ and $0.81 \%(95 \% \mathrm{CI}$ : $0.05-1.10 \%$ ), respectively. Multiple logistic regression analysis identified the total number of cows in the property as a risk factor for the presence of anti-B. abortus antibodies, with an odds ratio (OR) of 1.93 (95\% CI: $1.12-3.34)$ for herds with 30 to 210 cows and 7.81 (95\% CI: 3.72-16.38) for those with more than 210 cows, relative to the risk in herds with less than 30 cows, the base category. While these results demonstrate a significant reduction in the prevalence of properties with bovine brucellosis, the disease is still present in Minas Gerais, with properties with higher numbers of cows at higher risk for infection.
\end{abstract}

Key words: Bovine. Brucella abortus. Prevalence. Risk factors. Minas Gerais. Brazil.

\footnotetext{
${ }^{1}$ Coordenadora Estadual, Programa Nacional de Controle e Erradicação de Brucelose e Tuberculose Animal, Instituto Mineiro de Agropecuária, IMA, Belo Horizonte, MG, Brasil. Pesquisadora, Escola de Veterinária, Universidade Federal de Minas Gerais, UFMG, Belo Horizonte, MG, Brasil. E-mail: luciana.oliveira@ima.mg.gov.br

2 Prof $^{\mathrm{a}}$, Departamento de Medicina Veterinária, Universidade Federal de Lavras, UFLA, Lavras, MG, Brasil. Pesquisadora, Escola de Veterinária, Universidade Federal de Minas Gerais, UFMG, Belo Horizonte, MG, Brasil E-mail: elaine.dorneles@dmv.ufla.br

${ }_{3}^{3}$ Médica Veterinária, Pesquisadora, Faculdade de Agronomia e Medicina Veterinária, Universidade de Brasília, UnB, Brasília, DF, Brasil.E-mail: analourdes@unb.br

${ }^{4}$ Prof., Faculdade de Agronomia e Medicina Veterinária, UNB, Brasília, DF, Brasil. E-mail: vitorspg@unb.br

5 Profs., Faculdade de Medicina Veterinária e Zootecnia, Universidade de São Paulo, USP, São Paulo, SP, Brasil. E-mail: jsoares@, vps.fmvz.usp.br; fernando@vps.fmvz.usp.br; dias@vps.fmvz.usp.br; bufalo@usp.br; grisi@vps.fmvz.usp.br; marcosbryan@ usp.br; amaku@vps.fmvz.usp.br

6 Prof., Departamento de Medicina Veterinária Preventiva, Escola de Veterinária, Universidade Federal de Minas Gerais, UFMG, Belo Horizonte, MG, Brasil. E-mail: alage@vet.ufmg.br

* Author for correspondence
} 


\title{
Resumo
}

\begin{abstract}
Um estudo transversal foi realizado no estado de Minas Gerais, Brasil, em 2011, para estimar a soroprevalência da brucelose bovina (Brucella abortus) em propriedades e bovinos e identificar possíveis fatores de risco para a infecção nos rebanhos com fêmeas em idade reprodutiva. O estado foi regionalizado em sete estratos: 1. Regiões Noroeste, Norte e Nordeste; 2. Região Leste; 3. Região Central; 4. Região da Zona da Mata; 5. Regiões Sul e Sudoeste; 6. Região do Alto Paranaíba; 7. Região do Triângulo Mineiro, e a amostragem foi aleatória em dois estágios: de propriedades e, posteriormente, de bovinos em cada uma das mesmas. Foram coletadas amostras de sangue de 18.990 fêmeas em idade reprodutiva em 2.185 propriedades. Os testes sorológicos utilizados na detecção de anticorpos contra B. abortus foram o teste do antígeno acidificado tamponado e, como confirmatório, o teste de redução do 2-Mercaptoetanol, rotina preconizada pelo Programa Nacional de Controle e Erradicação da Brucelose e Tuberculose Animal (PNCEBT). O resultado da soroprevalência da brucelose bovina em propriedades e animais foi de 3.59\% (IC 95\%: 2,76-4,42\%) e 0,81\% (IC 95\%: 0,05-1,10\%), respectivamente. A análise de regressão logística multipla revelou como fatores de risco para a presença da infecção o número de fêmeas na propriedade com Odds Ratio (OR) de 1,93 (IC 95\%: 1,12-3,34) para os rebanhos de 30 a 210 fêmeas e de 7,81 (IC 95\%: 3,72-16,38) para aqueles com mais de 210 fêmeas, sempre em comparação ao risco dos rebanhos com menos de 30 fêmeas. Os resultados indicam que, apesar da redução na prevalência de focos na última década, a brucelose bovina ainda se encontra presente em Minas Gerais, havendo um maior risco de infecção em propriedades com maior número de animais.

Palavras-chave: Bovino. Brucella abortus. Prevalência. Fatores de risco. Minas Gerais. Brasil.
\end{abstract}

\section{Introduction}

Bovine brucellosis, caused by the bacterium Brucella abortus, is a zoonosis with worldwide distribution and responsible for significant economic losses associated with cattle farming (BERNUÉS et al., 1997; ALVES et al., 2015). In Brazil, the annual economic impact of bovine brucellosis in cattle herds was estimated at 32 million dollars (MAPA, 1971; POESTER et al., 2002), but 2013 estimates suggest a total loss due to the presence of bovine brucellosis of R\$ 892 million for the Brazilian herd, taking into account the costs involved with abortions, stillbirths, subfertility, involuntary discharge, decreased milk and beef production, and cost of veterinary interventions, among other costs (SANTOS et al., 2013). These costs may be even higher if the large differences in prevalence between states are also taken into account (ALVES et al., 2015).

The main clinical signs of bovine brucellosis are reproductive problems, including abortion in the final third of pregnancy, affecting up to $80 \%$ of the cows in a susceptible herd upon its first introduction (BISHOP et al., 1994). In addition to abortion, the disease may also cause stillbirths, birth of weak calves, placental retention, temporary or permanent infertility, perinatal mortality, and chronic or diffuse interstitial mastitis, among other problems (CORBEL, 2006; LAGE et al., 2008; XAVIER et al., 2009; POESTER et al., 2013). In males, infection can cause orchitis, epididymitis, decrease spermatozoa quality, and subfertility or sterility (CAMPERO, 1990; LAGE et al., 2008; POESTER et al., 2013). Articular lesions may occur in both sexes, typically as arthritis and bursitis (LAGE et al., 2008).

Despite the worldwide distribution of bovine brucellosis, the World Organization for Animal Health (OIE) has declared some countries to be disease-free, including Australia and New Zealand (OIE, 2014). Other countries, such as Canada and the United States, still have some cases, which are directly connected to infections in wild animals (RAGAN, 2002; OIE, 2014). In various South American countries, sero-epidemiologic studies have demonstrated a large variation in the apparent prevalence of cattle seropositive for $B$. abortus, albeit differences in geographical stratification and methodologies; from $2.10 \%$ in 
Argentina (AZNAR et al., 2014), 3.15\% (2000) to $1.62 \%$ (the first six months of 2014) in Paraguay (BAUMGARTEN, 2002; SENACSA, 2014), 1.22\% in Bolivia (MANRIQUE et al., 2005), 0.2\% in Chile (LOPETEGUI, 2011), and $0.04 \%$ in Uruguay (GARIN, 2011).

In Brazil, several seroprevalence studies were performed between 1975 and 2001, using various epidemiological methodologies, which revealed variations in the prevalence of positive properties, from around $0.4 \%$ in the state of Santa Catarina, to $32.0 \%$ in Goiás (ANSELMO; PAVEZ, 1977; POESTER et al., 2002). Given the importance of bovine brucellosis to the national livestock scenario, the Programa Nacional de Controle e Erradicação da Brucelose e Tuberculose Animal - PNCEBT (National Program for the Control and Eradication of Animal Brucellosis and Tuberculosis) was created by the Ministério da Agricultura Pecuária e Abastecimento - MAPA (Ministry of Agriculture, Livestock and Supply) in 2001 (BRASIL, 2001). The main objective of the PNCEBT is the reduction of the prevalence and incidence of both diseases and the establishment of a number of properties certified as free or monitored for brucellosis and tuberculosis. The prevention and control strategies adopted by the PNCEBT are based on compulsory actions: vaccination of cattle and buffalo heifers aged between three and eight months against brucellosis with the S19 vaccine, control of animal transit for breeding, and culling of animals diagnosed as positive for brucellosis; and voluntary actions: free or monitored property certification. From 2001 to 2004, in addition to the deployment of the procedures established by PNCEBT, 18 states performed prevalence studies with methodological standardization, reporting prevalences varying between $0.32 \%$ to $41.5 \%$ of seropositive herds in the states of Santa Catarina and Mato Grosso do Sul, respectively (ALVES et al., 2009; AZEVEDO et al., 2009; CHATE et al., 2009; DIAS et al., 2009a, 2009b; GONÇALVES et al., 2009a, 2009b;
KLEIN-GUNNEWIEK et al., 2009; MARVULO et al., 2009; NEGREIROS et al., 2009; OGATA et al., 2009; ROCHA et al., 2009; SIKUSAWA et al., 2009; SILVA et al., 2009; VILLAR et al., 2009; BORBA et al., 2013; ALMEIDA et al., 2016; CLEMENTINO et al., 2016). The states of Rondônia, Mato Grosso, Mato Grosso do Sul, Santa Catarina, São Paulo, Espírito Santo, and Rio Grande do Sul have performed a second assessment of the seroprevalence of brucellosis in these regions, about ten years apart from the first study. Of these, only Mato Grosso, Mato Grosso do Sul, and Rondônia reported a decrease in the prevalence of positive herds due to vaccination (BARDDAL et al., 2016; BAUMGARTEN et al., 2016; DIAS et al., 2016; ANZAI et al., 2016; INLAMEA et al., 2016; LEAL FILHO et al., 2016; SILVA et al., 2016).

In the state of Minas Gerais, B. abortus seroprevalence studies performed in 1975, 1980, and 2002 reported prevalences in properties and cattle of $17.70 \%$ and $6.30 \%$ (ANSELMO; PAVEZ, 1977), 20.50\% and 6.60\% (CASTRO, 1982), and $6.04 \%$ and $1.09 \%$ (GONÇALVES et al., 2009a), respectively. Based on the results of the 1980 study, the state of Minas Gerais created a voluntary brucellosis vaccination program in calves, which became compulsory in a regionalized form in 1994 (MINAS GERAIS, 1994) and for the whole Minas Gerais state territory in 1998 (MINAS GERAIS, 1997). In the last decade, the state has reported an average vaccination coverage of $79.50 \%$ (IMA, 2014).

As systematic evaluation of the indicators of morbidity, such as prevalence, is essential for the development of control and eradication programs, the objectives of this study were to estimate the prevalence of anti- $B$. abortus antibodies in properties and cattle and to analyze the potential risk factors associated with seropositivity in herds, in order to propose changes and new strategies for disease control and eradication of the disease in Minas Gerais. 


\section{Material and Methods}

\section{Study population}

A cross-sectional epidemiological study was performed in the state of Minas Gerais, located in the southeastern region of Brazil, with a geographical area of $586,522 \mathrm{~km}^{2}$ (IBGE, 2014) and a cattle herd with 23,965,914 individuals (IBGE, 2012), which represents $61.14 \%$ of the bovine herd in the southeastern region and $11.3 \%$ of the national herd. The Minas Gerais bovine herd is the secondlargest herd in the nation, and the largest dairy herd (ANUALPEC, 2014). Minas Gerais has the highest milk production in the country, with $23.70 \%$ of the cows in the region used for milking (IBGE, 2012).
In this study, the state was divided in seven regions (strata) of bovine production (Figure 1) in order to characterize differences between regional epidemiological profiles, including production systems, management practices, breeds, average herd size, marketing methods, and sanitary practices (ALVES, 2009; GONÇALVES et al., 2009a; OLIVEIRA, 2016). The strata were the same as those described in a previous study on the prevalence of brucellosis in Minas Gerais (GONÇALVES et al., 2009a) and validated by Alves (2009) and Oliveira (2016).

Figure 1. Map of the state of Minas Gerais, showing the regions defined in the current study. The state was divided into seven regions: 1. Noroeste, Norte and Nordeste; 2. Leste; 3. Central; 4. Zona da Mata; 5. Sul and Sudoeste; 6. Alto Paranaíba; and 7. Triângulo Mineiro.

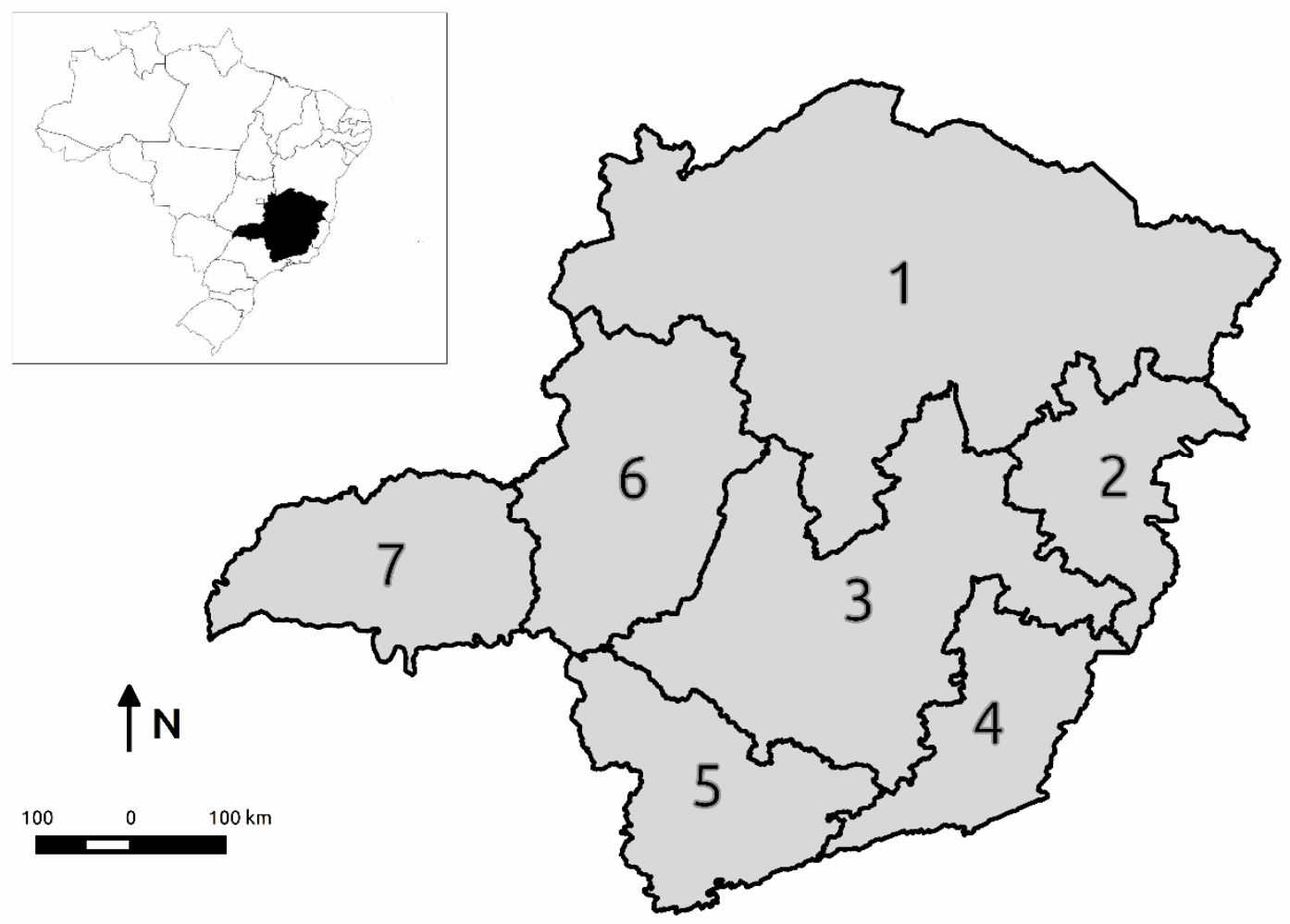

\section{Sample collection}

Population data provided by the Instituto Mineiro de Agropecuária (IMA), the Animal Health Protection Agency of Minas Gerais, were used as the basis for the sampling calculations (IMA VA-1/2010) (IMA, 2010). Table 1 summarizes the population and sample data in each of the seven producing regions of Minas Gerais defined in this study. 
Table 1. Census data of the bovine population in the state of Minas Gerais, Brazil, in 2010, according to productive regions.

\begin{tabular}{llcccc}
\hline Stratum & \multicolumn{1}{c}{ Regions } & $\begin{array}{c}\text { Total herds with } \\
\text { reproductive } \\
\text { activity }\end{array}$ & Herds sampled & $\begin{array}{c}\text { Total cows } \geq 24 \\
\text { months of age }\end{array}$ & $\begin{array}{c}\text { Sampled cows } \\
\mathbf{2 4} \text { months of } \\
\text { age }\end{array}$ \\
\hline 1 & Noroeste, Norte e Nordeste & 78,754 & 303 & 9,382 & 2,521 \\
2 & Leste & 26,275 & 297 & 15,279 & 2,803 \\
3 & Central & 80,555 & 367 & 10,785 & 2,979 \\
4 & Zona da Mata & 44,752 & 310 & 85,81 & 2,510 \\
5 & Sul and Sudoeste & 61,899 & 305 & 70,62 & 2,299 \\
6 & Alto Paranaíba & 30,147 & 301 & 13,534 & 2,909 \\
7 & Triângulo Mineiro & 23,789 & 302 & 17,775 & 2,969 \\
\hline Total & Minas Gerais & 346,171 & 2,185 & 82,398 & 18,990 \\
\hline
\end{tabular}

The sampling procedure for estimating the apparent prevalence of herds and cattle seropositive for $B$. abortus comprised two phases, starting with a random selection of a pre-established number of primary units (properties/herds), followed by assessment of the health status of the herd by random selection of a pre-established number of secondary units (cows at least 24 months of age). In situations in which the initial primary units needed to be replaced, the nearest property with similar productive characteristics was selected instead, when possible. The number of selected properties for the seven regions was estimated in accordance with the formula for simple random samples proposed by Noordhuizen et al. (1997) and Thrusfield (2005). The following parameters were used to calculate the primary unit sample sizes (properties/herds): degree of confidence of 0.95 , expected apparent prevalence $7.1 \%$ - upper limit of the confidence interval for the estimation of the prevalence of the herd in the seroepidemiological study by Gonçalves et al. (2009a) in 2002; and accuracy or absolute error of 0.03 . The sample sizes of the secondary units (animals) were calculated to allow sensitivity and specificity of the herd equal to or greater than $90 \%$. Hence, in herds with up to 99 cows at least 24 months of age, 10 cows or all cows (if there were fewer than 10 cows in the herd) were sampled, and 15 animals were sampled in herds with 100 or more cows at least 24 months of age. All female animals that were in the peripartum period (15 days before or after delivery) were excluded from the sampling. Thus, 18,990 cows at least 24 months of age were sampled from 2,185 herds with reproductive activity in the state of Minas Gerais. The collections were concentrated in 2011 (2,169 properties; 99.27\%), but started in 2010 ( 1 property, $0.05 \%$ ) and ended in 2012 (15 properties; 0.69\%).

Potential risk factors for the occurrence of $B$. abortus were assessed using an epidemiological questionnaire applied to all sampled herds. This questionnaire included factors reported in the scientific literature as associated with bovine brucellosis, such as management type, operation type, herd size, predominant breeds, number of cows, use of artificial insemination, purchase and sale of animals for reproductive purposes, methods of disposal of placental waste, use of calving pasture, presence of other domestic and wild species, veterinary care, and history of abortions on the property.

\section{Serologic tests}

Blood samples were collected by puncture of the jugular vein, using one sterile disposable needle per animal. The diagnostic protocol incorporated two serial tests to increase the specificity of diagnosis. In accordance with the recommendations of the PNCEBT (BRASIL, 2006), the Rose Bengal Test 
(RBT) was used as a screening test, followed by the confirmatory 2-mercaptoethanol reduction test (2ME). All tests were performed by the Laboratório de Saúde Animal - LSA (Laboratory of Animal Health) of the IMA using antigens produced by Instituto de Tecnologia do Paraná (Paraná's Technology Institute) (Tecpar, Brazil).

\section{Calculation of apparent prevalence in herds and animals}

A property was considered positive based on the detection of at least one positive cow with the confirmatory test $(2 \mathrm{ME})$. Due to the sample planning, it was possible to calculate the prevalence of brucellosis infected herds and infected animals for both the state of Minas Gerais and the seven regions individually. The calculations of apparent prevalences of herds and animals were performed using Stata version 12® (Statacorp, USA), considering the number of properties and existing animals in each strata (IMA, 2011), properties and animals sampled and number of properties and seropositive animals. The number of properties and existing animals in the stratum, according to the municipalities inserted into each of them, were extracted from the 2011 VA-1 Report (IMA, 2011), since $99.27 \%$ of the properties were sampled in 2011. The confidence intervals (CIs) of these prevalences were obtained by the exact binomial distribution, also using Stata version 12. The determination of prevalence coefficient (herds and animals) in each of the seven strata was performed using the following formulas to calculate the relative weight of each herd (P1) and each animal (P2) in the stratum (DOHOO et al., 2003):

$$
\mathrm{P} 2=\frac{\text { Number of cows } \geq 24 \text { months in the property }}{\text { Number of cows } \geq 24 \text { months sampled in the }} \mathrm{X}
$$

The number of cows $\geq 24$ months in stratum

Number of cows $\geq 24$ months in the properties sampled in the stratum
In formula $\mathrm{P} 2$, the first term refers to the weight of each animal inside the property; the second term refers to the weight of each animal within its respective strata (GONÇALVES et al., 2009a).

\section{Study of risk factors}

The analysis of risk factors for brucellosis was performed based on data collected from the questionnaires as well as the results of the laboratory diagnosis from the transversal study. The data were stored in an Access ${ }^{\circledR} 1997$ database (Microsoft Corporation, USA). The variables were organized in increasing scale of risk (VASCONCELLOS et al., 1987; ACHA; SZYFRES, 2001; PAULIN; FERREIRA NETO, 2003).

In some cases, variables were re-categorized for adequacy of the provision of the data to the reality of the data in the State, making it more representative in the final results. For the variable 'Total number of cows in the herd' the categorization was based on the cumulative distribution in percentiles $(50 \%$ and $95 \%$, respectively); in the state, herds with up to 29 cows were considered small; those with 30 to 210 cows, average; and large herds were those with more than 210 cows.

Initially, an exploratory univariate analysis was performed using the Chi-squared test, to identify variables with $\mathrm{P} \leq 0.20$ (ZAR, 2010); the lower risk category was always maintained as a basis for comparison to other risks. The selected variables were analyzed by multivariate logistic regression analysis, following a forward process of data entry in the final logistic regression model drawn up in the design-based format using variables with $\mathrm{P} \leq$ 0.05 (HOSMER JÚNIOR; LEMESHOW, 1989). This methodology of design-based analysis takes into consideration the calculated value of the weights of the properties sampled according to the stratum within the state, allowing for inference of the population character in the analysis of risk factors (HOSMER JÚNIOR; LEMESHOW, 1989). All logistic regression calculations were performed using Stata version 12 (Statacorp, USA). 
Spatial analysis of brucellosis-infected herds in the state of Minas Gerais

To verify the occurrence of spatial groupings of seropositive properties, we applied the $\mathrm{K}$ function to test the hypothesis of random identification of cases and controls: $\mathrm{K}_{11}(\mathrm{~h})=\mathrm{K}_{22}(\mathrm{~h})=\mathrm{K}_{12}(\mathrm{~h})$. The graph of $\hat{\mathrm{K}}_{11}(\mathrm{~h})-\hat{\mathrm{K}}_{22}$ (h) was used as a distance function (h) to investigate the occurrence of departure from the assumption of random identification between the upper and lower limits of the proposed curve. The program R (R CORE TEAM, 2014) using the 'splancs', 'maptools', 'rgdal' and 'rgeos' packages (BIVAND; RUNDEL, 2014; BIVAND; LEWINKOH, 2015; BIVAND et al., 2015; ROWLINGSON; DIGGLE, 2015) were used in these analyzes, as well as for the calculation of the upper and lower envelopes $\left(\mathrm{K}_{11}\right.$ and $\left.\mathrm{K}_{22}\right)$. A total of 1,000 simulations were performed to obtain these values, which were compared to with the significance of the peaks of those functions (BAILEY; GATRELL, 1995; DRUCK et al., 2004).

\section{Results}

Of 2,185 herds analyzed, 82 had at least one animal seropositive for $B$. abortus. Table 2 shows the apparent seroprevalence of $B$. abortus in seven productive regions as well as the weighted results for the cattle herd across the entire state. Table 3 shows the apparent weighted prevalence of animals seropositive for B. abortus. Of 18,990 cows tested, 113 were seropositive, resulting in an apparent prevalence of animals in the state of Minas Gerais of $0.81 \%$ (95\% CI: 0.05-1.10) (Table $3)$. The comparison of the prevalence of herds and animals seropositive for $B$. abortus obtained in the current study with that reported by the study performed in 2002 (GONÇALVES et al., 2009a) is shown in Figure 2. Only the Leste (stratum 2) and the Triângulo Mineiro (stratum 7) regions showed a significant reduction in the prevalence of herds seropositive for brucellosis, based on comparison of the confidence intervals, from the 2002 to 2011 studies (Figure 2). Similarly, the comparison of the results of the present study for the state of Minas Gerais with those of the study conducted in 2002 (GONÇALVES et al., 2009a), also showed a significant difference in prevalence rates of herds seropositive for brucellosis. However, there was no significant reduction in the prevalence of seropositive animals in any of the evaluated strata, as well as for the state overall, when comparing these results with those of the 2002 study (GONÇALVES et al., 2009a) (Figure 3).

Table 2. Apparent prevalence of herds seropositive for Brucella abortus in seven cattle-producing regions and overall in the state of Minas Gerais, 2011.

\begin{tabular}{llcccc}
\hline \multirow{2}{*}{ Stratum } & \multicolumn{1}{c}{ Regions } & Sampled & Positive & \multirow{2}{c}{$\begin{array}{c}\text { Prevalence } \\
\mathbf{( \% )}\end{array}$} & $\begin{array}{c}\text { CI } \\
(\mathbf{9 5 \%})\end{array}$ \\
\cline { 3 - 4 } & Noroeste, Norte e Nordeste & 303 & 8 & 2.68 & $0.84-4.52$ \\
2 & Leste & 297 & 6 & 2.02 & $0.41-3.62$ \\
3 & Central & 367 & 13 & 3.49 & $1.62-5.36$ \\
4 & Zona da Mata & 310 & 15 & 4.83 & $2.44-7.22$ \\
5 & Sul and Sudoeste & 305 & 11 & 3.60 & $1.51-5.70$ \\
6 & Alto Paranaíba & 301 & 14 & 4.56 & $2.22-6.89$ \\
7 & Triângulo Mineiro & 302 & 15 & 5.06 & $2.56-7.56$ \\
Total & Minas Gerais & 2,185 & 82 & 3.59 & $2.76-4.42$ \\
\hline
\end{tabular}


Table 3. Apparent prevalence of cattle seropositive for Brucella abortus in seven cattle-producing regions and overall in the state of Minas Gerais, 2011.

\begin{tabular}{llcccc}
\hline \multirow{2}{*}{ Stratum } & \multicolumn{1}{c}{ Regions } & \multicolumn{2}{c}{ Animals } & Prevalence & CI \\
& & Sampled & Positive & (95\%) \\
\hline 1 & Noroeste, Norte e Nordeste & 2,521 & 10 & 0.77 & $0.00-1.72$ \\
2 & Leste & 2,803 & 09 & 1.06 & $0.00-2.24$ \\
3 & Central & 2,979 & 22 & 0.76 & $0.16-1.35$ \\
4 & Zona da Mata & 2,510 & 20 & 1.23 & $0.31-2.14$ \\
5 & Sul and Sudoeste & 2,299 & 17 & 0.55 & $0.15-0.94$ \\
6 & Alto Paranaíba & 2,909 & 16 & 0.78 & $0.20-1.36$ \\
7 & Triângulo Mineiro & 2,969 & 19 & 0.67 & $0.26-1.07$ \\
\hline Total & Minas Gerais & 18,990 & 113 & 0.81 & $0.05-1.10$ \\
\hline
\end{tabular}

Figure 2. Coefficients of the prevalence of herds and cattle seropositive for Brucella abortus in the study performed in 2002 (GONÇALVES et al., 2009a) and in the present study (2011).

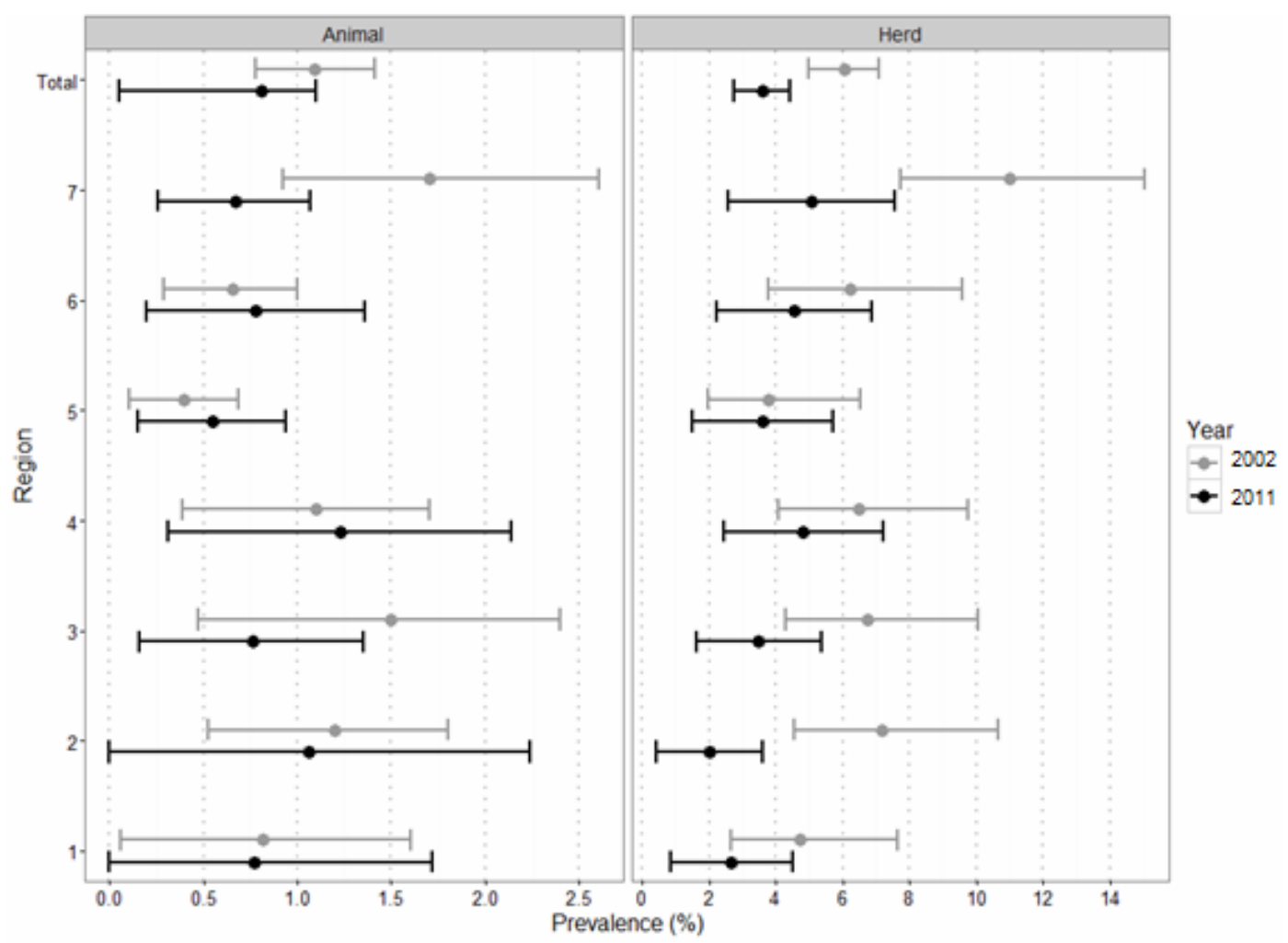


Figure 3. Differences between $\mathrm{k}$ functions for herds seropositive and seronegative for B. abortus in the state of Minas Gerais, 2011 (dotted lines represent the upper and lower limits of the envelope; the continuous line represents the observed spatial pattern).

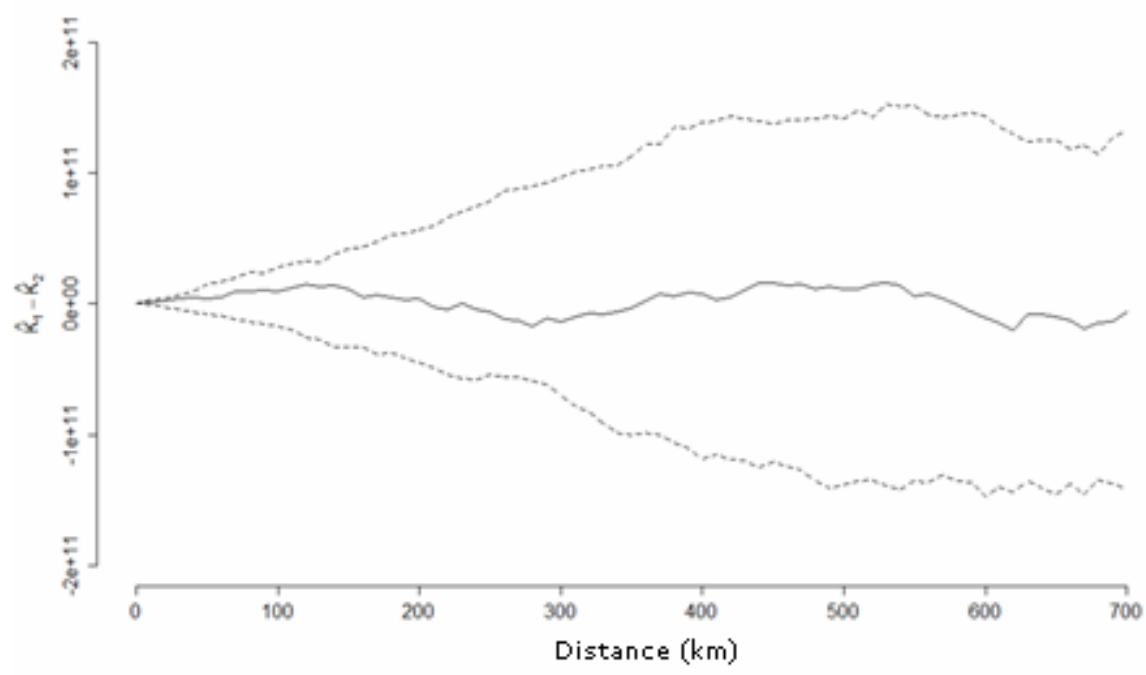

The following variables had $\mathrm{P} \leq 0.20$ in chisquare tests, and were, therefore, included in the multivariate logistic regression analysis of potential risk factors for the occurrence of B. abortus in cattle herds in the state of Minas Gerais: breed $(\mathrm{P}=$ $0.056)$, presence of sheep and goats on the property $(\mathrm{P}=0.018)$, presence of cats in the property $(\mathrm{P}=$ 0.101 ), history of abortions on the property ( $\mathrm{P}$ $=0.067)$, diagnostic testing for brucellosis $(\mathrm{P}<$ $0.001)$, purchase $(\mathrm{P}=0.028)$ and sale $(\mathrm{P}=0.022)$ of breeding animals, brucellosis vaccination $(\mathrm{P}=$ 0.096), slaughter of breeding animals $(\mathrm{P}<0.001)$, pasture rental $(\mathrm{P}=0.095)$, presence of a maternity paddock on the property $(\mathrm{P}<0.001)$, destination of milk produced $(\mathrm{P}=0.096)$, cooling of milk produced $(\mathrm{P}=0.064)$, consumption of raw milk $(\mathrm{P}$ $=0.049)$, use of veterinary assistance $(\mathrm{P}=0.001)$ and the number of cows in the herd $(\mathrm{P}<0.001)$. These variables were included in the multivariate logistic regression model following a forward process data entry drawn up in the design-based format (HOSMER JÚNIOR; LEMESHOW, 1989). The only variable with $\mathrm{P} \leq 0.05$ that remained in the final model, and thus considered a risk factor for the occurrence of brucellosis infection in the state of Minas Gerais, was the total number of cows of the herd (Table 4).

Table 4. Results of multivariate logistic regression analysis of the association of risk factors with bovine brucellosis in herds from the state of Minas Gerais, 2011.

\begin{tabular}{|c|c|c|c|}
\hline Variable & Odds ratio & $95 \% \mathrm{CI}$ & $\mathbf{P}$ \\
\hline \multicolumn{4}{|c|}{ Total number of cows in the herd } \\
\hline$\leq 29$ & Base category & & \\
\hline $30 \leq x \leq 210$ & 1.93 & $1.12-3.34$ & 0.018 \\
\hline$>210$ & 7.81 & $3.72-16.38$ & 0.000 \\
\hline
\end{tabular}


Figure 3 shows the results of the clustering analysis of properties seropositive for B. abortus in the state of Minas Gerais. There was no evidence of clustering since the curve given by $\hat{\mathrm{K}}_{11}(\mathrm{~h})-\hat{\mathrm{K}}_{22}(\mathrm{~h})$ was not outside the limits of the upper and lower envelopes from 1,000 independent simulations.

\section{Discussion}

The apparent prevalence of properties and cattle seropositive for $B$. abortus found in this study indicates that brucellosis is still present in the state of Minas Gerais, with a homogeneous distribution across the seven productive regions, regardless of the productive characteristics of the herds (Tables 2 and 3). In fact, spatial analysis did not identify clusters of infected herds, which confirms the homogeneous distribution of properties seropositive for bovine brucellosis in these regions. However, the apparent prevalence of $3.59 \%$ (95\% CI: $2.76-$ $4.42 \%$ ) of herds seropositive for brucellosis in the present study shows a significant reduction in the prevalence of the disease in cattle herds in Minas Gerais compared to the reported prevalence in 2002 (6.04\%; 95\% CI: 5.0 to $7.1 \%$ ) (GONÇALVES et al., 2009a) (Figure 2). This reduction was probably the result of the reduction of the prevalence of significant infected herds in the Leste and Triângulo Mineiro regions (strata 2 and 7), since the other sections showed identical coefficients of prevalence compared to those reported in 2002 and 2011. The restriction of these positive results to the Leste and the Triângulo Mineiro regions can be explained by the fact that they were also the two strata with the highest prevalence of brucellosis in the 2002 survey (GONÇALVES et al., 2009a); and that brucellosis vaccination produces faster effects when the original indices of the disease are higher (AMAKU et al., 2009; ALVES et al., 2015).

The state of Minas Gerais has had a state brucellosis vaccination program since the early 1990s (MINAS GERAIS, 1997; OLIVEIRA, 2016), unlike other Brazilian states, which deployed a compulsory vaccination only after the creation of the PNCEBT in 2001 (BRASIL, 2001). Since the establishment of the PNCEBT, the animal health protection service of the state, in addition to applying epidemiological surveillance measures, including control of animals for interstate transit and participation in events, monitoring of infected herds, and destruction of positive animals, also maintains a vaccination program with an average vaccination coverage between 2004 and 2014 of $79.5 \%$ (IMA, 2014; OLIVEIRA, 2016). Moreover, $92.95 \%$ of the properties sampled in this study reported regular brucellosis vaccination. Therefore, it is plausible to relate the decline in the seroprevalence of herds positive for brucellosis observed in the current study to the effectiveness of the systematic application of the control measures recommended by the PNCEBT, with a greater emphasis on vaccination and maintenance of a satisfactory vaccine coverage throughout its territory. However, it is important to recognize the challenges the state will encounter in reaching new significant reductions in the prevalence of infected herds based only on the maintenance of the vaccination program and the current vaccination coverage (AMAKU et al., 2009). This hypothesis is corroborated by the results of the present study, showing that most of the strata (stratum 1, 3, 4, 5 , and 6), which had low rates of the disease in 2002, did not present significant reductions in the seroprevalence of herds in 2011 compared to 2002 (Figure 2).

Likewise, the apparent prevalence of cattle seropositive for B. abortus was not statistically lower than that observed in 2002 (GONÇALVES et al., 2009a) (Figure 2), which may be due to the low prevalence rates of seropositive animals observed in the previous study, which, as discussed earlier, is difficult to reduce when the control programs of brucellosis are based heavily on compulsory vaccination (AMAKU et al., 2009; ALVES et al., 2015). One must stress that, as in the 2002 study (GONÇALVES et al., 2009a), the region in the Sul and Sudoeste (stratum 5) presented a lower apparent 
seroprevalence, although there were no statistically significant differences between the seven regions (strata 1 to 7) (Table 3).

The multivariate logistic regression analysis of risk factors indicated that the total number of cows in the herd was associated with an increased risk of bovine brucellosis. Analysis of the association of seropositive properties with the number of cows in the herd revealed a 1.93 -fold higher probability of the occurrence of the disease in herds of 30 to 210 cows compared to herds with up to 29 cows (Table 4). The risk increased to 7.81-fold higher in herds with more than 210 cows compared to those with up to 29 cows (Table 4). The herds with less than 29 cows corresponded to the 50th percentile in relation to the number of cows in the properties sampled, while herds with more than 210 cows corresponded to the $99^{\text {th }}$ percentile; that is, the proportion of herds classified as small (under 29 cows) is significant in the state of Minas Gerais. The association of other variables, such as the total number of animals or the total number of cows with increased risk of $B$. abortus infection in the herd has previously been demonstrated in studies of seroprevalence performed in other Brazilian States and elsewhere (NICOLETTI, 1980; SALMAN; MEYER, 1984; CRAWFORD et al., 1990; HOMEM, 2003; AZEVEDO et al., 2009; DIAS et al., 2009b; VILLAR et al., 2009; KLEIN-GUNNEWIEK et al., 2009; CHATE et al., 2009; NEGREIRO et al., 2009; SILVA et al., 2009, OGATA et al., 2009). In a 2011 global analysis of prevalence studies performed in 14 states (Bahia, Espírito Santo, Goiás, Distrito Federal, Mato Grosso, Paraná, Rondônia, Minas Gerais, Santa Catarina, Rio de Janeiro, Rio Grande do Sul, São Paulo, Sergipe e Tocantins), this association was proven, regardless of the region or state in the country (MOTA et al., 2016). Some characteristics of larger herds facilitate the transmission of brucellosis, particularly the increased need for replacement of animals, greater difficulty in implementing disease control measures, and the inherent dynamics of brucellosis (CRAWFORD et al., 1990). Christie (1969) observed a direct association between herd size and probability of disease occurrence, infection persistence, and the difficulty in eradicating brucellosis. Therefore, the larger the size of the herd, the greater the risk of introducing brucellosis and also the probability of its spreading within the herd.

It was not possible to confirm the relationship between seroprevalence in properties and cattle with the production characteristics of herds, such as type of management or breed. Thus, the occurrence of herds infected with brucellosis in the state may be influenced by factors not included in the proposed model for the analysis of risk factors. Dohoo et al. (2003) emphasized the limitations of transversal studies used to identify risk factors. These data, together with the low seroprevalence of brucellosispositive properties in this state, may indicate the need to replace cross-sectional studies with longitudinal studies, such as case-control studies, in order to improve our understanding of the risk factors of bovine brucellosis in Minas Gerais and to assess the adequacy of control measures.

The following results of the current study could be considered when formulating the control and epidemiological surveillance activities for bovine brucellosis in the state of Minas Gerais by the State Agency for Animal Health Protection (IMA): $\mathrm{i}$ - the homogenous distribution of seroprevalence of brucellosis-positive properties in the seven productive regions, reinforced by the result of the spatial analysis; and ii - the association of higher risk of occurrence of brucellosis in herds with more than 210 cows, a stratum that represented the last percentile of the distribution of the number of cows per property sampled.

The results of this study suggest that only vaccination will not be enough for significant reduction in the seroprevalence of properties positive for bovine brucellosis in the state of Minas Gerais. Nevertheless, it is important to maintain the vaccination program, with vaccine coverage above 
$80 \%$, mainly for the properties with a higher number of cows. Moreover, the establishment of incentive policies for producers is necessary to ensure the viability of the strategies already recommended by the PNCEBT. Cost-benefit analyses on the types of voluntary measure proposed by the PNCEBT have been performed by Lôbo (2008) and Leite (2012), who demonstrated the need for an additional compensation per liter of milk and allowance for diagnostic tests so that producers can obtain a return on their investment in this process.

It will not be possible to compel producers to test and eliminate brucellosis-positive animals or to reorganize infected herds based only on proven improvements in productive and reproductive performance, with consequent increase in revenue generation. In the before mentioned stimulus policies, it is important to involve not only public entities, by offering subsidies for brucellosis testing and stimulus as structured compensation funds, but also dairy houses and slaughterhouses, by means of additional compensation for milk and meat produced in demonstrably better sanitary conditions (disease-controlled properties or certified as diseasefree). Taking as an example the path followed by the United States (RAGAN, 2002), it is evident that understanding and shared efforts between the federal government, state, and rural producers will be indispensable for the eradication of bovine brucellosis in the state of Minas Gerais.

The epidemiological scenario of low prevalence of properties and cows seropositive for bovine brucellosis presented by this study, added to the financial contribution of an indemnity fund, subsidies for completion of diagnostic tests, and additional compensation for milk production by agribusinesses, will make it possible for the state of Minas Gerais to move toward eradication of bovine brucellosis.

Thus, the present study revealed a significant difference in the prevalence of herds infected with brucellosis in the state of Minas Gerais. However, the disease still displays a low prevalence of infected herds and animals, distributed homogeneously throughout the state. In addition, an increase in the risk of brucellosis in properties with a higher number of cows was observed.

\section{Acknowledgements}

The authors are grateful to the Instituto Mineiro de Agropecuária (IMA) for the application of the questionnaires and collection of samples in the properties as well as their processing in the LSA/IMA; to the Centro Colaborador Mapa em Saúde Animal: LAB/EV/UFMG, EpiPlan/UnB; LEB/FMVZ/ USP, for sample delineation and support during the statistical analysis and epidemiological surveillance of the obtained data. This study had the financial support of the following funding organizations: the Coordenação de Aperfeiçoamento de Pessoal de Nível Superior (CAPES), Conselho Nacional de Desenvolvimento Científico e Tecnológico (CNPq), Fundação de Amparo à Pesquisa do estado de Minas Gerais (Fapemig), Fundação de Apoio ao Ensino, Pesquisa e Extensão (FEPE/EV/UFMG) and Fundação de Auxílio à Pesquisa do Estado de São Paulo (Fapesp). APL was funded by a $\mathrm{CNPq}$ productivity fellowship and was also indebted to the Programa Pesquisador Mineiro - PPM - Fapemig (00923-15).

\section{References}

ACHA, P. N.; SZYFRES, B. Zoonosis y enfermedades transmissibles comunes al hombre y los animales. Washington: Organización Panamericana de la Salud, 2001. 398 p. (Publicación científica, 580).

ALMEIDA, E. C.; FREITAS, A. A.; PONTUAL, K. A. Q.; SOUZA, M. M. A.; AMAKU, M.; DIAS, R. A.; FERREIRA, F.; TELLES, E. O.; HEINEMANN, M. B.; GONÇALVES, V. S. P.; EVÊNCIO NETO, J.; MARVULO, M. F. V.; GRISI-FILHO, J. H. H.; FERREIRA NETO, J. S.; SILVA, J. C. R. Prevalence and associated risk factors for bovine brucellosis in the state of Pernambuco, Brazil. Semina: Ciências Agrárias, Londrina, v. 37, n. 5, p. 3413-3424, 2016. Suplemento 2. 
ALVES, C. Caracterização do perfil produtivo da pecuária bovina do estado de Minas Gerais, 2002. 2009. Dissertação (Mestrado em Ciência Animal) - Escola de Veterinária, Universidade Federal de Minas Gerais, Belo Horizonte.

ALVES, A. J. S.; GONÇALVES, V. P. S.; FIGUEIREDO, V. C. F.; LOBO, J. R.; BAHIENSE, L.; AMAKU, M.; FERNANDO, F.; FERREIRA NETO, J. S.; DIAS, R. A. Situação epidemiológica da brucelose bovina no Estado da Bahia. Arquivo Brasileiro de Medicina Veterinária e Zootecnia, Belo Horizonte, v. 61, p. 6-13, 2009. Suplemento 1 .

AMAKU, M.; DIAS, R. A.; FERREIRA NETO, J. S.; FERREIRA, F. Modelagem matemática do controle de brucelose bovina por vacinação. Arquivo Brasileiro de Medicina Veterinária e Zootecnia, v. 61, p.135-141, 2009. Suplemento 1.

ANSELMO, F. P.; PAVEZ, M. M. Diagnóstico de saúde animal. Brasília: Ministério da Agricultura, 1977. 735 p.

ANUALPEC. Anuário da Pecuária Brasileira: 2014. São Paulo: FNP, 2014. 303 p.

ANZAI, E. K.; COSTA, D.; SAID, A. L. P. R.; GRISI-FILHO, J. H. H.; AMAKU, M.; DIAS, R. A.; FERREIRA, F.; GALVIS, J. O. A.; GONÇALVES, V. S. P.; HEINEMANN, M. B.; TELLES, E. O.; FERREIRA NETO, J. S. An update on the epidemiological situation of bovine brucellosis in the state of Espírito Santo, Brazil. Semina: Ciências Agrárias, Londrina, v. 37, n. 5, p. 3425-3436, 2016. Suplemento 2.

AZEVEDO, S. S.; FERREIRA NETO, J. S.; DIAS, R. A.; FERREIRA, F.; AMAKU, M.; FIGUEIREDO, V. C. F.; LOBO, J. R.; GONÇALVES, V. S. P.; SOUZA, A. C.; VASCONCELLOS, S. A. Situação epidemiológica da brucelose bovina no Estado do Espírito Santo. Arquivo Brasileiro de Medicina Veterinária e Zootecnia, Belo Horizonte, v. 61, p. 19-26, 2009. Suplemento 1.

AZNAR, M. N.; SAMARTINO, L. E.; HUMBLET, M. F.; SAEGERMAN, C. Bovine brucellosis in Argentina and bordering countries. Transboundary and Emerging Disease, Berlin, v. 61, p. 121-133, 2014.

BAILEY, T. C.; GATRELL, A. C. Interactive spatial data analysis. Harlow: Prentice Hall, 1995. 413 p.

BARDDAL, J. E. I.; SANTOS, J. C. Q.; LOPES, I. F.; FERREIRA NETO, J. S.; FERREIRA, F.; AMAKU, M.; DIAS, R. A.; TELLES, E. O.; GRISI-FILHO, J. H. H.; HEINEMANN, M. B.; GONÇALVES, V. S. P.; AGUIAR, D. M. Effect of vaccination in lowering the prevalence of bovine brucellosis in the state of Mato Grosso, Brazil. Semina: Ciências Agrárias, Londrina, v. 37, n. 5, p. 3479-3492, 2016. Suplemento 2.
BAUMGARTEN, D. Brucellosis: a short review of the disease situation in Paraguay. Veterinary Microbiology, Amsterdam, v. 90, n. 1-4, p. 63-69, 2002.

BAUMGARTEN, K. D.; VELOSO, F. P.; GRISI-FILHO, J. H. H.; FERREIRA, F.; AMAKU, M.; DIAS, R. A.; TELLES, E. O.; HEINEMANN, M. B.; GONÇALVES, V. S. P.; FERREIRA NETO, J. S. Prevalence and risk factors for bovine brucellosis in Santa Catarina State, Brazil. Semina: Ciências Agrárias, Londrina, v. 37, n. 5, p. 3425-3436, 2016. Suplemento 2.

BERNUÉS, A.; MANRIQUE, E.; MAZA, M. T. Economic evaluation of bovine brucellosis and tuberculosis eradication programmes in a mountain area of Spain. Preventive Veterinary Medicine, Amsterdam, v. 30, n. 2, p. 137-149, 1997.

BISHOP, G. C.; BOSMAN, P. P.; HERR, S. Bovine brucellosis. In: COETZER, J. A. N.; THOMSON, G. R.; TUSTIN, R. C. (Ed.). Infectious diseases of Livestock. Austin: Texas A\&M University Press, College Station, 1994. v. 2, p. 1053-1066.

BIVAND, R.; KEITT, T.; ROWLINGSON, B. Rgdal: bindings for the geospatial data abstraction library. $\mathrm{R}$ package version 0.9-2. [S.1. : s.n.], 2015. Available at: $<$ http://CRAN.R-project.org/package $=$ rgdal $>$. Accessed at: 24 apr. 2015.

BIVAND, R.; LEWIN-KOH, N. Maptools: tools for reading and handling spatial objects. R package version 0.8-36. [S.1. : s.n.], 2015. Available at: $<$ http://CRAN.Rproject.org/package $=$ maptoolsoject.org/package $=$ rgeos $>$. Accessed at: 24 apr. 2015.

BIVAND, R.; RUNDEL, C. Rgeos: interface to geometry engine - open source (GEOS). R package version 0.3-8. [S.1. : s.n.], 2014. Available at: <http://CRAN.R-project. org $/$ package $=$ maptools $>$. Accessed at: 24 apr. 2015.

BORBA, M. R.; STEVENSON, M. A.; GONÇALVES, V. S. P.; FERREIRA NETO, J. S.; FERREIRA, F.; AMAKU, M.; TELLES, E. O.; SANTANA, S. S.; FERREIRA, J. C. A; LÔBO, J. R.; FIGUEIREDO, V. C. F.; DIAS, R. A. Prevalence and risk-mapping of bovine brucellosis in Maranhão State, Brazil. Preventive Veterinary Medicine, Amsterdam, v. 110, n. 2, p. 169-176, 2013.

BRASIL. Secretaria de Defesa Animal, Ministério da Agricultura, Pecuária e Abastecimento,Instrução Normativa SDA n. 2, de 10 de janeiro de 2001. Diário Oficial [da] União, Brasília, 4 jun. 2001. Seção 1, p. 2631.

BRASIL. Ministério da Agricultura, Pecuária e Abastecimento. Departamento de Defesa Animal. Programa nacional de controle e erradicação da brucelose e tuberculose (PNCEBT) - manual técnico. Brasília: MAPA, 2006. 188 p. 
CAMPERO, C. M.; LADDS, P. W.; HOFFMANN, D.; DUFFIELD, B.; WATSON, D.; FORDYCE, G. Immunopathology of experimental Brucella abortus strain 19 infection of the genitalia of bulls. Veterinary Immunology and Immunopathology, v. 24, p. 235-246, 1990.

CASTRO, D. Prevalência da brucelose nas áreas trabalhadas pelo IESA em Minas Gerais-1980. Boletim IESA, Belo Horizonte, v. 1, n. 1, p. 1-12, 1982.

CHATE, S. C.; DIAS, R. A.; AMAKU, M.; FERREIRA, F.; MORAES, G. M.; COSTA NETO, A. A.; MONTEIRO, L. A. R. C.; LOBO, J. R.; FIGUEIREDO, V. C. F.; GONÇALVES, V. S. P.; FERREIRA NETO, J. S. Situação epidemiológica da brucelose bovina no Estado do Mato Grosso do Sul. Arquivo Brasileiro de Medicina Veterinária e Zootecnia, Belo Horizonte, v. 61, p. 46-55, 2009. Suplemento 1.

CHRISTIE, T. E. Eradication of brucellosis in Northern Ireland: field problems and experiences. Veterinary Research, Paris, v. 85, p. 268-269, 1969.

CLEMENTINO, I. J.; DIAS, R. A.; AMAKU, M.; FERREIRA, F.; TELLES, E. O.; HEINEMANN, M. B.; GONÇALVES, V. S. P.; GRISI-FILHO, J. H. H.; FERREIRA NETO, J. S.; ALVES, C. J.; SANTOS, C. S. A. B.; AZEVEDO, S. S. Epidemiological situation of bovine brucellosis in the state of Paraiba, Brazil. Semina: Ciências Agrárias, Londrina, v. 37, n. 5, p. 3403-3412, 2016. Suplemento 2.

CORBEL, M. J. World health organization, food and agriculture organization of the United Nations \& International Office of Epizootics. Brucellosis in humans and animals. Geneva: World Health Organization, 2006. $89 \mathrm{p}$.

CRAWFORD, R. P.; HUBER, J. D.; ADAMS, B. S. Epidemiology and surveillance. In: NIELSEN, K.; DUNCAN, J. R. (Ed.). Animal brucellosis. Boca Raton: CRC Press, 1990. p. 131-151.

DIAS, J. A.; MÜLLER, E. E.; DIAS, R. A.; FREITAS, J. C.; AMAKU, M.; FERREIRA, F.; SILVA, M. C. P.; LOBO, J. R.; FIGUEIREDO, V. C. F.; GONÇALVES, V. S. P.; FERREIRA, NETO, J. S. Situação epidemiológica da brucelose bovina no Estado do Paraná. Arquivo Brasileiro de Medicina Veterinária e Zootecnia, Belo Horizonte, v. 61, p. 66-76, 2009a. Suplemento 1.

DIAS, R. A.; GONÇALVES, V. S. P.; FIGUEIREDO, V. C. F.; LOBO, J. R.; LIMA, Z. M. B.; PAULIN, L. M. S.; GUNNEWIEK, M. F. K.; AMAKU, M.; FERREIRA NETO, J. S.; FERREIRA, F. Situação epidemiológica da brucelose bovina no Estado de São Paulo. Arquivo Brasileiro de Medicina Veterinária e Zootecnia, Belo Horizonte, v. 61, p. 118-125, 2009b. Suplemento 1.
DIAS, R. A.; BELCHIOR, A. P. C.; FERREIRA, R. S.; GONÇALVES, R. C.; AGUIAR, R. S. C. B.; SOUSA, P. R.; SANTOS, A. M. A.; AMAKU, M.; FERREIRA, F.; TELLES, E. O.; GRISI-FILHO, J. H. H.; HEINEMANN, M. B.; GONÇALVES, V. S. P.; FERREIRA NETO, J. S. Controlling bovine brucellosis in the State of São Paulo, Brazil: results of ten years of vaccination program. Semina: Ciências Agrárias, v. 37, n. 5, p. 3505-3518, 2016. Suplemento 2.

DOHOO, I.; MARTIN, W.; STRYHN, H. Veterinary epidemiologic research. Charlottetown: Atlantica Veterinary College, 2003. 706 p.

DRUCK, S.; CARVALHO, M. S.; CÂMARA, G.; MONTEIRO, A. V. M. (Ed.). Análise espacial de dados geográficos. Brasília: EMBRAPA, 2004. 209 p.

GARIN, A. Program of control/eradication of bovine brucellosis in Uruguay. In: BRUCELLOSIS 2011. INTERNATIONAL RESEARCH CONFERENCE, 2011, Buenos Aires. Proceedings... Buenos Aires: Asociación Argentina de Microbiologia, 2011. p. 18-19.

GONÇALVES, V. S. P.; DELPHINO, M. K. V. C.; DIAS, R. A.; FERREIRA, F.; AMAKU, M.; FERREIRA NETO, J. S.; PORTO, T. B.; ALVES, C. M.; FIGUEIREDO, V. C. F.; LOBO, J. R. Situação epidemiológica da brucelose bovina no Estado de Minas Gerais. Arquivo Brasileiro de Medicina Veterinária e Zootecnia, Belo Horizonte, v. 61, p. 35-45, 2009a. Suplemento 1.

GONÇALVES, V. S. P.; RIBEIRO, L. A.; CALDAS, R. A.; FRANCISCO, P. F. C.; DIAS, R. A.; FERREIRA, F.; AMAKU, M.; FERREIRA NETO, J. S.; FIGUEIREDO, V. C. F.; LOBO, J. R.; BORGES, J. R. J. Situação epidemiológica da brucelose bovina no Distrito Federal. Arquivo Brasileiro de Medicina Veterinária e Zootecnia, Belo Horizonte, v. 61, p. 14-18, 2009b. Suplemento 1.

HOMEM, V. S. F. Brucelose e tuberculose bovinas no município de Pirassununga, São Paulo: prevalências, fatores de risco e estudo econômico. 2003. Tese (Doutorado em Medicina Veterinária) - Faculdade de Medicina Veterinária e Zootecnia, Universidade de São Paulo, São Paulo.

HOSMER JÚNIOR, D. W.; LEMESHOW, S. Applied logistic regression. New York: John Wiley \& Sons, 1989. $307 \mathrm{p}$.

INSTITUTO MINEIRO DE AGROPECUÁRIA IMA. Relatório histórico vacinação contra brucelose em Minas Gerais. Belo Horizonte: Instituto Mineiro de Agropecuária, 2014. (Relatório não publicado).

Relatório VA-1 Maio de 2010. Belo Horizonte: Instituto Mineiro de Agropecuária, 2010. Relatório não publicado. 
. Relatório VA-1 Maio de 2011. Belo Horizonte: Instituto Mineiro de Agropecuária, 2011. Relatório não publicado.

INLAMEA, O. F.; ROCHA, A. B.; FERREIRA, F.; GRISI-FILHO, J. H. H.; HEINEMANN, M. B.; DIAS, R. A.; TELLES, E. O.; GONÇALVES, V. S. P.; AMAKU, M.; FERREIRA NETO, J. S. Effect of vaccination in lowering bovine brucellosis in the state of Rondônia, Brazil. Semina: Ciências Agrárias, Londrina, v. 37, n. 5, p. 3493-3506, 2016. Suplemento 2.

INSTITUTO BRASILEIRO DE GEOGRAFIA E ESTATÍSTICA-IBGE. Estados@. Brasília: IBGE, 2014. Disponível em: $<$ http://www.ibge.gov.br/estadosat/perfil. php?sigla=mg $>$. Acesso em: 3 jun. 2014.

. Produção da pecuária municipal. Brasília: IBGE, 2012. Disponível em: <http://ftp.ibge.gov.br/Producao_ Pecuaria/Producao_da_Pecuaria_Municipal/2012/ ppm2012. pdf>. Acesso em: 24 ago. 2014.

KLEIN-GUNNEWIEK, M. F. C.; AMAKU, M.; DIAS, R. A.; FERREIRA, F.; GITTI, C. B.; PEREIRA, L. A.; FIGUEIREDO, V. C. F.; LOBO, J. R.; GONÇALVES, V. S. P.; FERREIRA NETO, J. S. Situação epidemiológica da brucelose bovina no Estado do Rio de Janeiro. Arquivo Brasileiro de Medicina Veterinária e Zootecnia, Belo Horizonte, v. 61, p. 77-84, 2009. Suplemento 1.

LAGE, A. P.; POESTER, F. P.; PAIXÃO, T. A.; SILVA, T. M. A.; XAVIER, M. N.; MINHARRO, S.; MIRANDA, K. L.; ALVES, C. M.; MOL, J. P. S.; SANTOS, R. L. Brucelose bovina: uma atualização. Revista Brasileira de Reprodução Animal, Belo Horizonte, v. 32, n. 5, p. 202212, 2008.

LEAL FILHO, J. M.; BOTTENE, I. F. N.; MONTEIRO, L. A. R. C.; PELlEGRIN, A. O.; GONÇALVES, V. S. P.; FERREIRA, F.; DIAS, R. A.; AMAKU, M.; TELLES, E. O.; GRISI-FILHO, J. H. H.; HEINEMANN, M. B.; FERREIRA NETO, J. S Control of bovine brucellosis from 1998 to 2009 in the state of Mato Grosso do Sul, Brazil. Semina: Ciências Agrárias, Londrina, v. 37, n. 5, p.3467-3478, 2016. Suplemento 2.

LEITE, B. M. Aspectos epidemiológicos e econômicos da certificação de propriedades leiteiras como livres de brucelose e tuberculose bovina. 2012. Dissertação (Mestrado em Saúde Animal) - Faculdade de Agronomia e Medicina Veterinária, Universidade Federal de Brasília, UnB, Brasília.

LÔBO, J. R. Análise custo-benefício da certificação de propriedades livres de tuberculose bovina. 2008. Dissertação (Mestrado em Agronegócio) - Faculdade de Agronomia e Medicina Veterinária, Universidade Federal de Brasília, UnB, Brasília.
LOPETEGUI, P. Strategy for eradicate bovine brucellosis in Chile. In: BRUCELLOSIS 2011. INTERNATIONAL RESEARCH CONFERENCE, 2011, Buenos Aires. Proceedings... Buenos Aires: Asociación Argentina de Microbiologia, 2011. p. 22.

MANRIQUE, S. J. J.; RAMOS, S. R.; GUZMÁN, C. J. Estudio epizootiológico de brucelosis bovina en el departamento de Santa Cruz. 2005. Tesis (Grado). Facultad de Ciencias Veterinarias. Bolivia.

MINISTÉRIO DA AGRICULTURA, PECUÁRIA E ABASTECIMENTO - MAPA. Programa Nacional de Controle e Erradicação da Brucelose e Tuberculose Animal (PNCEBT). Manual técnico. Brasília: MAPA, 2006. 184 p.

MINISTÉRIO DA AGRICULTURA, PECUÁRIA E ABASTECIMENTO - - MAPA. Departamento de Defesa Animal. Programa Nacional de controle e erradicação da brucelose e tuberculose (PNCEBT) Manual técnico. Brasília: MAPA, 2006. 188 p.

MARVULO, M. F. V.; FERREIRA, F.; DIAS, R. A.; AMAKU, M.; GROFF, A. C. M.; GONÇALVES, V. S. P.; FIGUEIREDO, V. C. F.; LOBO, J. R.; FERREIRA NETO, J. S. Situação epidemiológica da brucelose bovina no Estado do Rio Grande do Sul. Arquivo Brasileiro de Medicina Veterinária e Zootecnia, Belo Horizonte, v. 61, p. 93-102, 2009. Suplemento 1.

MINAS GERAIS. Instituto Mineiro de Agropecuária. Portaria n. 243, de 11 de junho de 1997. Torna obrigatória a vacinação contra a brucelose em todo o estado de Minas Gerais. Belo Horizonte, 11 jun. 1997. 3 p.

Portaria n. 139, de 06 de setembro de 1994. Amplia a área de vacinação obrigatória contra a brucelose e estabelece critérios. Belo Horizonte, 06 set. 1994. 3 p.

MOTA, A. L. A. A.; FERREIRA, F.; FERREIRA NETO, J. S.; DIAS, R. A.; GRISI-FILHO, J. H. H.; TELLES, E. O.; GONÇALVES, V. S. P. Large-scale study of herdlevel risk factors for bovine brucellosis in Brazil. Acta Tropica, Netherlands, v. 164, p. 226-232, 2016.

NEGREIROS, R. L.; DIAS, R. A.; FERREIRA, F.; FERREIRA NETO, J. S.; GONÇALVES, V. S. P.; SILVA, M. C. P.; FIGUEIREDO, V. C. F.; LÔBO, J. R.; FREITAS, J.; AMAKU, M. Situação epidemiológica da brucelose bovina no Estado do Mato Grosso. Arquivo Brasileiro de Medicina Veterinária e Zootecnia, Belo Horizonte, v. 61, p. 56-65, 2009. Suplemento 1.

NICOLETTI, P. The epidemiology of bovine brucellosis. Advances in Veterinary Science and Comparative Medicine, New York, v. 24, p. 69-98, 1980. 
NOORDHUIZEN, J. P. T. M.; FRANKENA, K.; VAN DER HOOFD, C. M.; GRAAT, E. A. M. Application of quantitative methods in veterinary epidemiology. Wageningen: Wageningen Press, 1997. 445 p.

OFFICE INTERNATIONAL DES ÉPIZOOTIES OIE. Disease information. Paris: OIE, 2014. Available

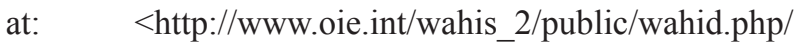
Diseaseinformation/statuslist - List of countries by disease situation>. Accessed at: 4 oct. 2014.

OGATA, R. A.; GONÇALVES, V. S. P.; FIGUEIREDO, V. C. F.; LOBO, J. R.; RODRIGUES, A. L.; AMAKU, M.; FERREIRA, F.; FERREIRA NETO, J. S.; DIAS, R. A. Situação epidemiológica da brucelose bovina no Estado do Tocantins. Arquivo Brasileiro de Medicina Veterinária e Zootecnia, Belo Horizonte, v. 61, p. 126134, 2009. Suplemento 1.

OLIVEIRA, L. F. Situação epidemiológica da brucelose bovina e caracterização da pecuária bovina no estado de Minas Gerais. 2012. Tese (Doutorado em Ciência Animal) - Escola de Veterinária, Universidade Federal de Minas Gerais, UFMG, Belo Horizonte.

PAULIN, L. M.; FERREIRA NETO, J. S. A experiência brasileira no combate à brucelose bovina. Jaboticabal: Funep, 2003. 154 p.

POESTER, F. P.; SAMARTINO, L. E.; SANTOS, R. L. Pathogenesis and pathobiology of brucellosis in livestock. Revue Scientifique et Technique: Office International des Épizooties, Paris, v. 32, n. 1, p. 105-116, 2013.

POESTER, F.; GONÇALVES, V. S. P.; LAGE, A. P. Brucellosis in Brazil. Veterinary Microbiology, Amsterdam, v. 90, n. 1-4, p. 55-62, 2002.

$\mathrm{R}$ CORE TEAM - R: a language and environment for statistical computing. Vienna: R Foundation for Statistical Computing, 2014. Available at: <http://www.R-project. org/>. Accessed at: 17 jun. 2015.

RAGAN, V. E. The animal and plant health inspection service (APHIS) brucellosis eradication program in United States. Veterinary Microbiology, Amsterdam, v. 90, n. 1-4, p. 11-18, 2002.

ROCHA, W. V.; GONÇALVES, V. S. P.; COELHO, C. G. N. F. L.; BRITO, W. M. E. D.; DIAS, R. A.; DELPHINO, M. K. V. C.; FERREIRA, F.; AMAKU, M.; FERREIRA NETO, J. S.; FIGUEIREDO, V. C. F.; LOBO, J. R.; BRITO, L. A. B. Situação epidemiológica da brucelose bovina no Estado de Goiás. Arquivo Brasileiro de Medicina Veterinária e Zootecnia, Belo Horizonte, v. 61, p. 27-34, 2009. Suplemento 1.
ROWLINGSON, B.; DIGGLE, P. Splancs: spatial and space-time pointpattern analysis. $\mathrm{R}$ package version 2.01-37. [S.1. : s.n.], 2015. Available at: $<$ http://CRAN.Rproject.org $/$ package $=$ splancs $>$. Accessed at: 17 jun. 2015 .

SALMAN, M. D.; MEYER, M. E. Epidemiology of bovine brucellosis in the Mexicali Valley, Mexico: literature review of disease-associated factors. American Journal of Veterinary Research, Chicago, v. 45, n. 8, p. 1557-1560, 1984.

SANTOS, R. L.; MARTINS, T. M.; BORGES, A. M.; PAIXÃO, T. A. Economic losses due to bovine brucellosis in Brazil. Pesquisa Veterinária Brasileira, Rio de Janeiro, v. 33, n. 6, p. 759-764, 2013.

SERVICIO NACIONAL DE CALIDAD Y SALUD ANIMAL - SENACSA. Publicación sanidad animal primer cuatrimestre. San Lorenzo: SENACSA, 2014. Disponible en: <http://www.senacsa.gov.py/index. $\mathrm{php} /$ servicios/estadisticas/estadistica-pecuaria-2014>. Consultado el: 17 jun. 2015.

SIKUSAWA, S.; ROCHA, W. V.; AMAKU, M.; DIAS, R. A.; FERREIRA NETO, J. S.; MARTINS, C.; GONÇALVES, V. S. P.; FIGUEIREDO, V. C. F.; LÔBO, J. R.; FERREIRA, F. Situação epidemiológica da brucelose bovina no estado de Santa Catarina. Arquivo Brasileiro de Medicina Veterinária e Zootecnia, Belo Horizonte, v. 61, p. 103-108, 2009. Suplemento 1.

SILVA, N. S.; GROFF, A. C. M.; VIDOR, A. C. M.; GRISI-FILHO, J. H. H.; HEINEMANN, M. B.; DIAS, R. A.; TELLES, E. O.; GONÇALVES, V. S. P.; AMAKU, M.; FERREIRA, F.; FERREIRA NETO, J. S. Epidemiological situation of brucellosis after implementation of the vaccination program in Rio Grande do Sul State, Brazil. Semina: Ciências Agrárias, Londrina, v. 37, n. 5, p. 3519-3530, 2016. Suplemento 2.

SILVA, V. G. S. O.; DIAS, R.A.; FERREIRA, F.;AMAKU, M.; COSTA, E. L. S.; LOBO, J. R.; FIGUEIREDO, V. C. F.; GONÇALVES, V. S. P.; FERREIRA NETO, J. S. Situação epidemiológica da brucelose bovina no Estado de Sergipe. Arquivo Brasileiro de Medicina Veterinária e Zootecnia, Belo Horizonte, v. 61, p. 109-117, 2009. Suplemento 1.

THRUSFIELD, M. Veterinary epidemiology. $3^{\text {th }}$ ed. Cambridge: Blackwell Science, 2005. 625 p.

VASCONCELLOS, S. A.; ITO, F. H.; CÔRTES, J. A. Bases para a prevenção da brucelose animal. Comunicação Científica da Faculdade de Medicina Veterinária e Zootecnia da Universidade de São Paulo, São Paulo, v. 11, n. 1, p. 25-36, 1987. 
VILLAR, K. S.; AMAKU, M.; DIAS, R. A.; FERREIRA NETO, J. S.; BENITEZ, F.; GONÇALVES, V. S. P.; FIGUEIREDO, V. C. F.; LOBO, J. R.; FERREIRA, F. Situação epidemiológica da brucelose bovina no Estado de Rondônia. Arquivo Brasileiro de Medicina Veterinária e Zootecnia, Belo Horizonte, v. 61, p. 85-92, 2009. Suplemento 1.
XAVIER, M. N.; PAIXÃO, T. A.; POESTER, F.; LAGE, A.P.; SANTOS, R. L. Pathological, immunohistochemical and bacteriological study of tissues and milk of cows and fetuses experimentally infected with Brucella abortus. Journal of Comparative Pathology, Liverpool, v. 140, n. 2-3, p. 149-157, 2009.

ZAR, J. H. Biostatistical analysis. $5^{\text {th }}$ ed. New Jersey: Prentice Hall, 2010. 944 p. 
